\title{
PHYTOCHEMICAL EVALUATION AND CYTOTOXICITY ASSAY OF LYTHRI HERBA EXTRACTS
}

\author{
IRINA MIHAELA IANCU ${ }^{1}$, LAURA ADRIANA BUCUR ${ }^{2 *}$, VERGINICA SCHRODER ${ }^{2}$, \\ HORAȚIU MIREȘAN ${ }^{2}$, MIHAI SEBASTIAN ${ }^{2}$, VALERIU IANCU ${ }^{2}$, VICTORIA BADEA ${ }^{1}$ \\ 1 "Ovidius" University of Constanța, Faculty of Dental Medicine, Department of Microbiology, 7 Ilarie Voronca Street, \\ Constanța, Romania \\ 2 "Ovidius” University of Constanța, Faculty of Pharmacy, 6 Căpitan Al. Șerbănescu Street, Constanța, Romania
}

*corresponding author: adrianabucur@yahoo.com

Manuscript received: July 2020

\begin{abstract}
Lythrum salicaria L. is a plant known in traditional European medicine for its healing effects for diseases such as dysentery and diarrhoea. The quantitative evaluation by spectrophotometric determinations of total polyphenols, tannins and anthocyanins content revealed values of $16.39 \%$ in polyphenols, $10.53 \%$ tannins and $0.3598 \%$ anthocyanosides, results comparable to the data in the literature. To determine the antioxidant activity of the aqueous extract the DPPH radical method was performed on the Lythri herba vegetal product. The aqueous extract shows an increased antioxidant activity (DPPH) of $94.39 \%$ for the concentration of $2.5 \mathrm{mg} / \mathrm{mL}, \mathrm{IC}_{50}$ being registered at $0.2166 \mathrm{mg} / \mathrm{mL}$. These results correlated with the effects of the biological activity of the extract on the Artemia salina L. biotester. Although the extract is non-toxic, cytological effects appear after $48 \mathrm{~h}$ (the accumulation of cytoplasmic inclusions, an increase of intercellular space and cell detachments at the level of the basement membrane).
\end{abstract}

\section{Rezumat}

Lythrum salicaria L. este una dintre plantele cunoscute în medicina tradiţională europeană pentru efectele curative în afecțiuni precum dizenteria și diareea. Evaluarea calității prin determinări spectrofotometrice a conținutului de polifenoli totali, taninuri şi antocianozide a scos în evidență valori de $16,39 \%$ polifenoli, 10,53\% taninuri și $0,3598 \%$ antocianozide, rezultate comparabile cu datele din literatură. Determinarea activității antioxidante a extractului apos a fost realizată prin metoda radicalului DPPH din produsul vegetal Lythri herba. Extractul apos arată o activitate antioxidantă crescută (DPPH) de 94,39\% pentru concentrația de $2,5 \mathrm{mg} / \mathrm{mL}$, IC 50 fiind înregistrat la $0,2166 \mathrm{mg} / \mathrm{mL}$. Aceste rezultate au fost corelate cu efectele activității biologice ale extractului asupra biotesterului Artemia salina L. Deși extractul este non-toxic, după $48 \mathrm{~h}$ apar efectele la nivel citologic (acumulări de incluziuni citoplasmatice, spațiu mărit intercelular și detaşări de celule la nivelul membranei bazale).

Keywords: Lythri herba, tannins, Artemia salina, antioxidant activity

\section{Introduction}

Over the years, the popularity of medicinal plants has declined compared to the pharmaceutical chemical industry and its multitude of synthetic compounds. The same can be said about Lythrum salicaria L. species (Lythraceae), a plant well known in the literature for its curative effects against dysentery and diarrhoea, even though Lythri herba is a standardized pharmacopoeial plant material [1].

Rehabilitating the importance of Lythrum salicaria L. species in the Romanian therapy is the main objective of this research. Lythrum salicaria L., known as purple loosestrife (răchitan in the Romanian language) in Romanian folk medicine, is used internally for gastrointestinal disorders due to its rich tannin composition, and externally for varicose veins, eczemas and bleeding gums [27]. Previous phytochemical studies have shown that polyphenols are the main compound of the aerial parts of the Lythrum salicaria L. species, which determine its pharmacological effects such as antidiarrheal, antimicrobial, anti-inflammatory and antioxidant properties [4, 28]. Important bioactive compounds such as tannins, flavonoids, anthocyanins, phenolic acids, alkaloids, steroids and triterpenes were revealed by numerous studies [28]. Other evaluations have showed that Lythrum salicaria L. extracts possess hypoglycaemic effects and can also reduce the plasma level of triglycerides [22, 28]. Ethanolic extracts of the Lythrum salicaria L. species have shown antimicrobial activity against Gram-negative and Gram-positive bacteria such as Staphylococcus aureus, Escherichia coli, Pseudomonas aeruginosa and as well as on the Candida albicans fungus [4]. The use of cytotoxicity tests for plant extracts can be expensive, due to their complex composition, with effects that require repeated tests while being correlated with various types of solvents and testers. Among the easiest methods, frequently used in such tests, is brine shrimp lethality assay (BSLA). This is considered a preliminary test 
for cytotoxicity testing, an important evaluation stage before modelling [15] and optimizations of assays, in pharmaceuticals studies. It is an in vivo test, performed on Artemia salina larvae, a crustacean species used in toxicology [5, 12], nano-toxicology [17], plant extracts testing and applications [8, 11, 14, 16, 24]. Meyer and Clarkson established the criteria for identifying plant extracts toxicity levels based on relevant concentrations [13, 23]. Therefore, Artemia salina becomes a most useful test model for these types of tests $[13,23]$. In addition, the possibility of highlighting cellular structures through transparency makes this test system an easy tool for evaluating the cytological changes $[29,31]$.

The aim of this study is to identify the phytochemical content of the Lythrum salicaria L. (Lythri herba) species, and to identify its cytotoxic potential. The plant has been studied internationally $[4,6,7,18]$ and is highly valued for its application of new extractioninduced epidermal regeneration data [18], but at the national level there is very little data or the data is incomplete in terms of active pharmacological activities.

The novelty and originality of the study is given by the fact that for the first time in Romania, an analysis of the correlation between the phytochemical composition and the biological activity of the extract is performed. In addition, the assessment of cytotoxicity involves the use of an in vivo test model, widely used for plant extracts and standardized, which replaces other test models just as effectively. This test is essential in establishing preliminary cytotoxicity, as it increases the efficiency of determining which concentration has toxic potential, used as an alternative for complex studies.

\section{Materials and Methods}

\section{Vegetal products}

Aerial parts of Lythrum salicaria L. (Lythri herba) were collected in August 2019 from the Năvodari area, Constanţa city, Romania, while a voucher specimen has been deposited in the exicata collection of the Pharmacognosy discipline within the Faculty of Pharmacy, "Ovidius” University in Constanţa, Romania. After harvesting, the plant material was sorted and cleaned of any leaves or flowers that were altered. Parts of the plant materials were kept in $70 \%$ alcohol in a jar with a running stopper, to carry out the cross sections while other parts were dried at room temperature, in the shade, for three weeks to use them for qualitative and quantitative examinations.

Loss on drying. We determined the loss of drying for the dry extract, because all subsequent determinations will relate to the mass of dried plant material. The method used for this preliminary determination is provided in both the European Pharmacopoeia 10.0 edition [1] and in the Romanian Pharmacopoeia $10^{\text {th }}$ edition monography (FR X) [2].

The assay of water-soluble substances and 50\% methanol study methods. This preliminary determination is performed to assess the degree of extractability of the solvents to choose the optimal solvent with which the most active principles are extracted. The method used for these determinations is standardized in FR X, and we used dried floral tips from Lythrum salicaria L. species from Romania [2] as the plant material. $5.0167 \mathrm{~g}$ of pulverized plant material is weighed on an analytical scale and transferred into a vial with a ground-in stopper; we added $100 \mathrm{~mL}$ of water, shook vigorously several times, left to macerate for 23 hours, stir again for 1 hour and filter, removing the first portions of the filtrate. $10 \mathrm{~g}$ of the filtrate are evaporated to dryness on a water bath in a pre-weighed weighing ampoule. The weighing ampoule was dried in an oven at $105^{\circ} \mathrm{C}$ for 3 hours, cooled in a desiccator and weighed. The residue is made up of the soluble substances and refers to $100 \mathrm{~g}$ of plant product [2]. Preparing the extracts

To obtain the dry extract, the air-dried plant material Lythri herba was milled to a powder (111.3081 g) using an electric blender and extracted with water (1000 mL) using a Soxhlet apparatus for 2 hours. After cooling, the extract was filtered and the filtrate was concentrated to evaporate the solvent with the BUCHI R-215 rotary evaporator. The residue was dried (approximately $12 \mathrm{~g}$ ), then transferred to a sealed glass recipient and stored in an exicator until we conducted the following experiments.

The assay of total polyphenols, tannins and anthocyanins

The tannin content of the dry plant extract was determined using the Folin-Ciocâlteu method according to the European Pharmacopoeia (EP) 10.0 edition [1]. To determine total polyphenols content, we performed the Folin-Ciocâlteu adapted method according to the EP 10.0 edition [1] while for determining the anthocyanins content we used the colorimetric method according to the EP 10.0 edition [1].

For total polyphenols and tannin determination, the amount of $0.5022 \mathrm{~g}$ dry extract was dissolved in $250 \mathrm{~mL}$ of water. Then, the resulting solution (solution A) was filtered through cotton wool in a $250 \mathrm{~mL}$ volumetric flask. $20 \mathrm{~mL}$ of water were added to solution A, thus creating solution B. Taking $2 \mathrm{~mL}$ of solution $\mathrm{B}$, we added $1 \mathrm{~mL}$ of Folin-Ciocâlteu reagent, $10 \mathrm{~mL}$ of water and $12 \mathrm{~mL}$ of $\mathrm{Na}_{2} \mathrm{CO}_{3} 290 \mathrm{~g} / \mathrm{L}$ solution. The resulting solution is left to stand for 30 minutes. The absorbance $\left(\mathrm{A}_{1}\right)$ is read at a wavelength of 760 $\mathrm{nm}$, using water as a compensation liquid.

In a $100 \mathrm{~mL}$ volumetric flask we brought $50 \mathrm{mg}$ of pyrogallol which is dissolved in $50 \mathrm{~mL}$ of water and fill up to the mark with water (stock solution). In a $100 \mathrm{~mL}$ volumetric flask we diluted $5 \mathrm{~mL}$ of the pyrogallol stock solution (dilute pyrogallol solution) with 
water. We took $2 \mathrm{~mL}$ of the diluted pyrogallol solution and we add $1 \mathrm{~mL}$ of the Folin-Ciocâlteu reagent, 10 $\mathrm{mL}$ of water and $12 \mathrm{~mL} \mathrm{Na}_{2} \mathrm{CO}_{3} 290 \mathrm{~g} / \mathrm{L}$ solution. The mixture took on a blue coloration. After 30 minutes, we read the absorbance $\left(\mathrm{A}_{2}\right)$ at the wavelength $\lambda=760$ $\mathrm{nm}$, using water as a compensating liquid.

The total polyphenols content was calculated according to the following formula:

$\%$ total polyphenols $=\left(62.5 \times \mathrm{A}_{1} \times \mathrm{m}_{2}\right) /\left(\mathrm{A}_{2} \times \mathrm{m}_{1}\right)$, where: $\mathrm{m}_{1}=$ mass of the examined sample $(\mathrm{g}), \mathrm{m}_{2}=$ pyrogallol mass $(\mathrm{g}), \mathrm{A}_{1}=$ total polyphenols absorbance $(\mathrm{nm}), \mathrm{A}_{2}=$ absorbance of the pyrogallol standard (nm). To calculate the tannin content, we used the previous method with the previous absorbances $\left(\mathrm{A}_{1}\right.$ and $\left.\mathrm{A}_{2}\right)$ and we calculated the third absorbance of non-adsorbed polyphenols on the skin powder.

Therefore, we used $10 \mathrm{~mL}$ of solution A and stirred with $0.10 \mathrm{~g}$ skin powder for 60 minutes, then filtered with filter paper. This resulting solution is solution $\mathrm{C}$. $2 \mathrm{~mL}$ from solution $\mathrm{C}$ was added over $1 \mathrm{~mL}$ FolinCiocâlteu reagent, $10 \mathrm{~mL}$ distilled water and $12 \mathrm{~mL}$ $\mathrm{Na}_{2} \mathrm{CO}_{3} 290 \mathrm{~g} / \mathrm{L}$ solution. After 30 minutes of rest, using water as the compensation liquid, the absorbance $\left(\mathrm{A}_{3}\right)$ at $760 \mathrm{~nm}$ of a $3 \mathrm{~mL}$ sample of the resulting solution was read.

The tannin content was calculated according to the following formula:

$\%$ tannins $=\left[62.5 \times\left(\mathrm{A}_{1}-\mathrm{A}_{3}\right) \times \mathrm{m}_{2}\right] /\left(\mathrm{A}_{2} \times \mathrm{m}_{1}\right)$,

where: $m_{1}=$ mass of the examined sample $(g), m_{2}=$ pyrogallol mass $(\mathrm{g}), \mathrm{A}_{1}=$ total polyphenols absorbance $(\mathrm{nm}), \mathrm{A}_{2}=$ absorbance of the pyrogallol standard (nm), $\mathrm{A}_{3}=$ absorbance of non-adsorbed polyphenols on the skin powder (nm).

To calculate the anthocyanins content, we used 1.0057 $\mathrm{g}$ of the powdered air-dried aerial parts of Lythrum salicaria L., which were extracted with $20 \mathrm{~mL}$ of methanol for 30 minutes, then filtered and brought to a $50 \mathrm{~mL}$ volumetric flask by washing the extract with the same solvent. $1 \mathrm{~mL}$ of this resulting solution is added over $9 \mathrm{~mL}$ of $0.1 \%$ hydrochloric acid in methanol. The absorbance of a $3 \mathrm{~mL}$ sample of the final solution was read at $528 \mathrm{~nm}$.

The anthocyanins content was calculated according to the following formula:

$\%$ anthocyanins expressed in cyanidol 3-glucoside = $(\mathrm{A} \times 1000) /(718 \times \mathrm{m})$,

where: $\mathrm{A}=$ absorbance of the examined sample $(\mathrm{nm})$, $\mathrm{m}=$ mass of the dry extract $(\mathrm{g}), 718=$ specific absorbance of cyanidol 3-glucoside.

The absorbents were determined using a UV-VIS Jasco V630 spectrophotometer.

DPPH (1,1'-Diphenyl-2-picryl-hydrazyl) radical scavenging activity

The DPPH radical method used in this study is a standardized method for evaluating the inactivation capacity of free radicals by phenolic compounds and is achieved by measuring the neutralization capacity of the DPPH radical (1,1'-diphenyl-2-picryl-hydrazyl) in reduced form to the analysed solution. The free radical scavenging activity of Lythri herba aqueous extract was determined by DPPH radical discoloration procedures described by Bucur L et al. [11]. The solution to be analysed or the obtained stock solution (P1) had a concentration of $2.5 \mathrm{mg} / \mathrm{mL}$, from which test solutions (P2 - P6) were obtained by diluting the initial plant extract with water $(\mathrm{P} 1)$. We determined an absorbance of $0.004 \%$ DPPH in methanol, after which we mixed it with the test solutions. The reaction mixtures were stirred, then incubated in the dark and at room temperature for 30 minutes, after which the absorbances of the test solutions were measured at $517 \mathrm{~nm}$.

The total scavenging ability of the extract was calculated with the following formula:

$\%$ scavenger activity $=\left[\left(\mathrm{A}_{\text {Initial }}-\mathrm{A}_{\text {Final }}\right) / \mathrm{A}_{\text {Initial }}\right] \times 100$, where: $A_{\text {Initial }}=$ absorbance before the addition of the plant extract, $A_{\text {Final }}=$ absorbance 30 minutes after the addition of the solution.

The reagents and apparatus used for this test are: 1,1'-diphenyl-2-picryl-hydrazyl (Aldrich), absolute methanol (Sigma-Aldrich), UV-VIS Jasco V630 spectrophotometer and a Kern Abj electronic analytical scale. The antioxidant activity of the aqueous extract from the Lythri herba plant material was expressed as an $\mathrm{IC}_{50}$ value (concentration of plant extract that scavenges $50 \%$ of the free radical) and was calculated from the concentration-effect linear regression curve.

Brine Shrimp Lethality Assay (BSLA)

The BSLA test was performed according to the EBPI protocol (Environmental Bio-detection Products Inc.) with modifications regarding ARTOXKIT protocol. Artemia salina eggs (JBL ARTEMIO cysts) were incubated in artificial seawater (Marine Sea Salt Tetra $\mathrm{GmbH}$, Germany) salinity solution (3.4 - 3.6\%o), in a volume of $1 \mathrm{~L}$, with aeration and continuous illumination, until the larvae appeared (24 - 30 h). After hatching, larvae in larval stage I (nauplius I) were separated and introduced into experimental vessels (with a volume of $1 \mathrm{~mL}$ ), in 2 - 3\%o saline solution. A number of 15 20 specimens were introduced in each test vessel. A multiwall test plate with $24(6 \times 4)$ test wells was used. For each extract, three concentrations $(\mathrm{C} 1 \mathrm{~W}$, $\mathrm{C} 2 \mathrm{~W}, \mathrm{C} 3 \mathrm{~W}$ ) in aqueous solution (W) and three concentrations (C1Al, C2Al, C3Al) in alcohol ( $\mathrm{Al})$, were used (Table I), and for each sample three repetitions were performed. To limit the effects of the alcohol, a volumetric report of 1:4 was performed in the case of the alcoholic extract. Samples without the extract were used as a control group. 


\begin{tabular}{lcc}
\hline \multicolumn{1}{c}{ Samples } & Concentration extract $(\boldsymbol{\mu g}$ herbal product/mL) & Larvae tested number \\
\hline C1W & $4.93 \times 10^{3}$ & 46 \\
C2W & $9.87 \times 10^{3}$ & 50 \\
C3W & $19.74 \times 10^{3}$ & 52 \\
C1Al & $0.98 \times 10^{3}$ & 48 \\
C2Al & $1.97 \times 10^{3}$ & 35 \\
C3Al & $3.94 \times 10^{3}$ & 57 \\
Control W (Water) & - & 43 \\
Control Al (Alcohol) & - & 42 \\
\hline
\end{tabular}

The evaluation of effects (survival or mortality) was performed after 24 and 48 hours. Several specimens were extracted and analysed under a microscope for cytological details after $24 \mathrm{~h}$. The Optika Italy, B-350 microscope, was used to observe details of the biotester organisms. A statistical analysis program (StatPlus Mac Pro, version v6, Analyst Soft Inc for MacOS) was used for interpretations. The survival values are expressed as mean \pm SD of three parallel measurements. Cytotoxicity was assessed and correlated with the

composition of the plant extract according to Clarkson's toxicity criterion [13].

\section{Results and Discussion}

The results obtained from the previous determinations were summarized in Table II.

The result obtained at loss on drying in an oven falls within the limits mentioned in the European Pharmacopoeia (EP) 10.0 edition of a maximum of $12 \%$ which ensures better preservation [1].

Table II

Results obtained from Lythri herba extract

\begin{tabular}{|c|c|c|c|c|c|c|}
\hline Assay & $\begin{array}{c}\text { Loss on drying } \\
(\%)\end{array}$ & $\begin{array}{c}\text { Substances } \\
\text { soluble in water } \\
(\%)\end{array}$ & $\begin{array}{c}\text { Substances soluble } \\
\text { in } 50 \% \text { methanol } \\
(\%)\end{array}$ & $\begin{array}{c}\text { Total } \\
\text { polyphenol } \\
\text { content } \\
(\%)\end{array}$ & $\begin{array}{c}\text { Tannin } \\
\text { content } \\
(\%)\end{array}$ & $\begin{array}{c}\text { Anthocyanin } \\
\text { content } \\
(\%)\end{array}$ \\
\hline Lythri herba extract & $7.5279 \% \pm 0.06$ & $17.215 \% \pm 0.22$ & $19.73 \% \pm 0.18$ & $16.39 \%$ & $10.53 \%$ & $0.3598 \%$ \\
\hline
\end{tabular}

The differences between the values obtained from determination of substances soluble in water and in $50 \%$ methanol are not significant and show that both water and $50 \%$ methanol can be considered optimal solvents to extract the most active principles from the Lythrum salicaria L. plant.

The assay of total polyphenols, tannins and anthocyanins

Polyphenols are a major group of active compounds with real therapeutic potential due to their antioxidant properties [9]. The total polyphenol content from Lythri herba dry extract falls within the results of other international specialized studies. Such values between $6.6 \%$ and $21.9 \%$ tannins and between $8.3 \%$ and $27.3 \%$ total polyphenols were quantified in the floral tops of Lythrum salicaria L. species from Hungary, depending on the harvest period $[6,7]$.

Tannins are one of the largest groups of plant polyphenols and have antiviral, anti-inflammatory, antibacterial, anti-carcinogenic activities and can be used as astringent, antiseptic and haemostatic agents [3]. The tannin content of Lythri herba dry extract falls within the thresholds mentioned in the EP 10.0 edition for at least $5 \%$ content of tannins [1].

Other studies showed higher polyphenol and tannin contents in the flowering top than in the leaves or stems of Lythrum salicaria L. plants [4]. The dry extract of the Lythri herba plant material has a content of $16.39 \%$ polyphenols, of which $10.53 \%$ are tannins.

Anthocyanins are plant pigments, derivatives of flavan, which give the flowers, fruits and other organs their red, purple or blue colours [10]. Anthocyanins are used especially as herbal dyes, but in traditional medicine they have been used for antidiabetic, antitumour, anti-inflammatory, antimicrobial and cardiovascular disease prevention, by stimulating the local synthesis of vasodilating prostaglandins $[20,30]$. The anthocyanins content of Lythri herba extract falls within the limits mentioned in the EP 10.0 edition for at least $0.3 \%$ of the anthocyanins expressed in cyanidol 3-glucoside for Myrtilli fructus recens plant material monography [1]. The existence of anthocyanins in the plant material of Lythri herba was also confirmed by the study of Paris R. and Paris M. in 1964. They revealed two dominant dyes, namely malvidin 3,5-diortho-glucoside and cyaniding 3-ortho-glucoside [26]. DPPH radical scavenging activity

The aqueous extract obtained from the Lythri herba plant material showed increased DPPH scavenger activity, namely $94.39 \%$ for a concentration of 2.5 $\mathrm{mg} / \mathrm{mL}$. The scavenging effect increased with the increasing concentration of the extract. The obtained results represent the means of three previously performed measurements and are illustrated in Table III. 
Table III

Sample DPPH scavenging activity

\begin{tabular}{|l|c|c|c|}
\hline \multirow{2}{*}{ Sample } & \multicolumn{3}{|c|}{ Parameter } \\
\cline { 2 - 3 } & Concentration $\mathbf{( m g / m L )}$ & DPPH scavenger activity $\mathbf{( \% )}$ & \multirow{2}{*}{$\mathbf{I C}_{\mathbf{5 0}} \mathbf{( m g / \mathbf { m L } )}$} \\
\hline P1 & 2.5 & 94.3934 & \multirow{2}{*}{} \\
\hline P2 & 1 & 92.3158 & \\
\hline P3 & 0.5 & 76.2155 & \\
\hline P4 & 0.25 & 50.0744 & \\
\hline P5 & 0.1 & 22.0974 & \\
\hline P6 & 0.05 & 16.7576 & \\
\hline
\end{tabular}

P1 = stock solution; P2 = diluted solution 1:1.5; P3 = diluted solution 1:4; P4 = diluted solution 1:9; P5 = diluted solution 1:24; P6 = diluted solution 1:49.

The $\mathrm{IC}_{50}$ value (concentration of plant extract that scavenges $50 \%$ of the free radical) was calculated from the concentration-effect linear regression curve $(0.2166$ $\mathrm{mg} / \mathrm{mL})$.

The study conducted by Turnalier et al. (2007) obtained an $\mathrm{IC}_{50}$ value of $0.1 \mathrm{mg} / \mathrm{mL}$ for the aqueous extract of the Lythri herba plant material from Turkey [32]. The study of Manany A. et al. in 2013 showed the antioxidant capacity of $80 \%$ methanolic extract from the Lythri herba plant material, Iran, obtaining a value of $\mathrm{IC}_{50}$ of $0.0135 \mathrm{mg} / \mathrm{mL}$ [22].
The $\mathrm{IC}_{50}$ value of the Lythri herba plant material falls within the ranges found in the international literature $[4,28]$.

Brine Shrimp Lethality Assay (BSLA)

The brine shrimp lethality assay (BSLA) is used in the evaluation of plant extracts to identify their cytotoxicity. The testing is performed on 24 hours larvae because the larvae have sufficient energy reserves to carry out the development processes in this stage. As a result, the response of these organisms to the tested substances and the induced cytotoxic behaviour, respectively, do not interfere with other substances in the test environment such as food.
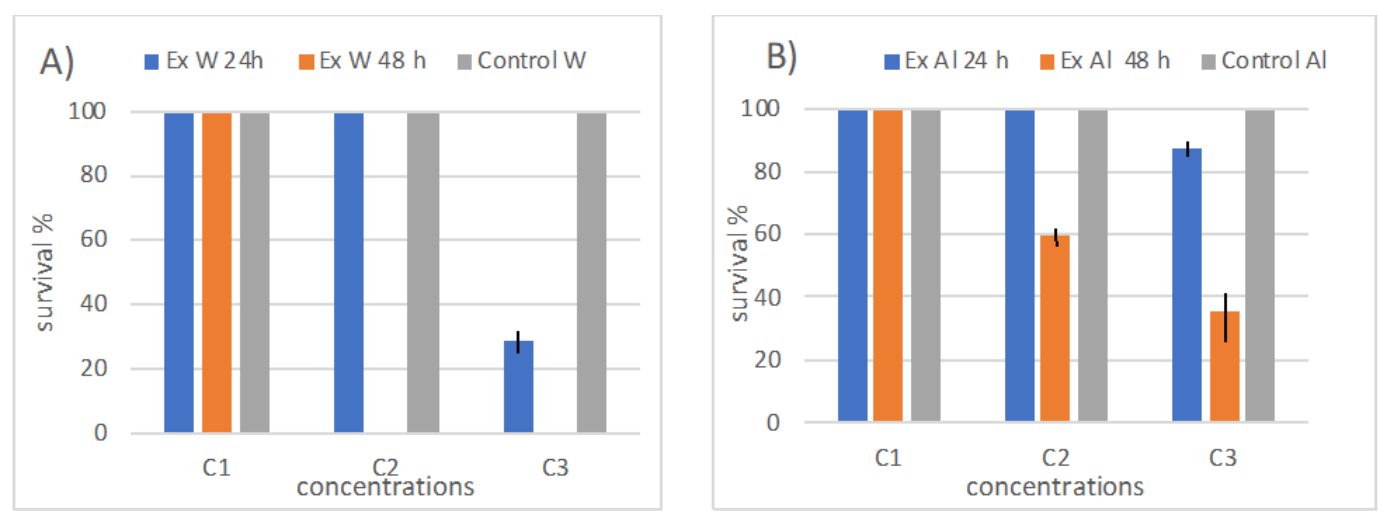

Figure 1.

Larval survival (\%) recorded at $24 \mathrm{~h}$ and $48 \mathrm{~h}$ from exposure in $\mathrm{Ex} \mathrm{W}(\mathbf{A})$ and $\mathrm{Ex} \mathrm{Al}(\mathbf{B})$ Data are mean values $\pm \mathrm{SD}, \mathrm{n}=3$

Ex W - Aqueous extract; Ex Al - Alcoholic extract; Control W - Control water; Control Al - Control alcohol

In the first 24 hours larvae survival was very high (100\%) after being exposed to extracts for concentrations $\mathrm{C} 1$ and $\mathrm{C} 2$. In the case of $\mathrm{C} 3$ we had a survival rate of $28.39 \%$ for the aqueous extract (Figure 1A), and $87.69 \%$ for the alcoholic extract (Figure 1B). At 48 hours the evolution was obviously unfavourable in the case of larvae exposed to higher concentrations, keeping their viability in the $\mathrm{C} 1 \mathrm{~W}$ and $\mathrm{C} 1 \mathrm{Al}$ containers. The answer correlates with the concentration level in the case of both tests (aqueous extract and alcoholic extract).

The death of the larvae is preceded by the modification of the specific movements of the antennae and, respectively, muscular coordination, the movements being affected by frequent, short, sudden and disordered interruptions.

The analysis revealed high toxicity of both extracts at high concentrations, after $48 \mathrm{~h}$ exposures. Probit analysis reveals the differences in toxicity when reporting the concentrations of compounds in the extract component (polyphenolic compounds and tannins). According to Clarkson's toxicity criterion, the average toxicity induced by the composition in tannins is also noted (Table IV) [13]. In the case of polyphenolic compounds, it is found that the toxicity is low (Table IV) [13]. 

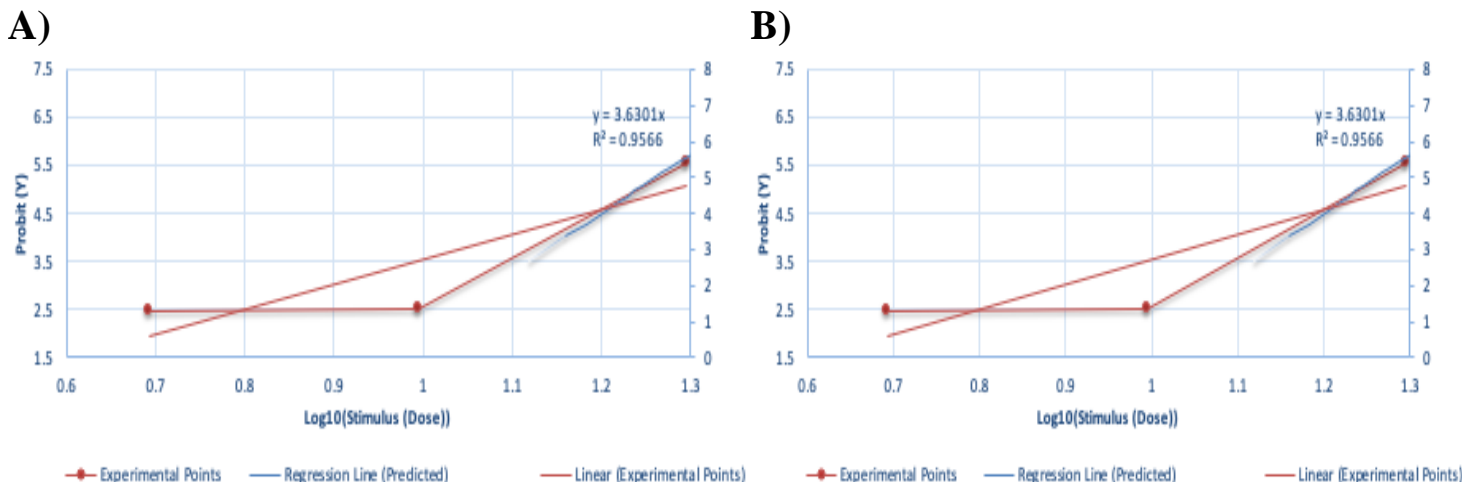

Figure 2.

Evaluation of the answers to the analysed extracts by Probit analysis at 48 hours

A) Aqueous extract (Ex W); B) Alcoholic extract (Ex Al)

The results of the probit analysis for the extracts, which were evaluated and reported separately on the compounds, highlight the differences in toxicity. These may be a reference to the fact that the extraction method (in aqueous solutions - Figure 2A, or in alcohol solutions - Figure 2B) influences the bioactivity of the extract.

The highlighted effect (in the case of BSLA the quantified effect is mortality) indicates the interaction between the cellular mechanisms and the complex composition of the extract. Mortality is correlated with the extract concentrations, as well as with the time of action of the extract on the tested organism. The lethal concentration was $\mathrm{LC}_{50}=18.24 \times 10^{3}$ for aqueous extract $(\mathrm{Ex} \mathrm{W})$ and $\mathrm{LC}_{50}=3.22 \times 10^{3}$, for alcoholic extract (Ex Al), after $48 \mathrm{~h}$. These results indicated non-toxic effects, after Clarkson's toxicity criterion, and is an important detail that these extracts can be used the natural alternatives for therapies.

Toxicity values induced by Lythri herba extracts expressed by $\mathrm{LC}_{50}$ and toxicity levels (after $48 \mathrm{~h}$ )

\begin{tabular}{|c|c|c|c|c|c|}
\hline \multirow[t]{2}{*}{ Extract } & \multirow[t]{2}{*}{$\mathbf{L C}_{50}(\mu \mathrm{g} / \mathrm{mL})$} & \multirow[t]{2}{*}{ Standard error $\mathrm{LC}_{50}$} & \multicolumn{2}{|c|}{ Confidence interval } & \multirow[t]{2}{*}{ Toxicity levels* } \\
\hline & & & Lower & Upper & \\
\hline Aqueous extract (Ex W) & $18.24 \times 10^{3}$ & $2.60 \times 10^{3}$ & $13.08 \times 10^{3}$ & $24.11 \times 10^{3}$ & non-toxic \\
\hline Alcoholic extract (Ex Al) & $3.22 \times 10^{3}$ & $0.86 \times 10^{3}$ & $1 \times 10^{3}$ & NA & non-toxic \\
\hline Polyphenols & 604.68 & 174 & 346.15 & 1056.29 & low toxic \\
\hline Tannins & 403.85 & 116.68 & 230.98 & 706.69 & medium toxic \\
\hline
\end{tabular}

*Clarkson's toxicity criterion (extracts with $\mathrm{LC}_{50}$ above $1000 \mu \mathrm{g} / \mathrm{mL}$ are non-toxic; $\mathrm{LC}_{50}$ of $500-1000 \mu \mathrm{g} / \mathrm{mL}$ are low toxic;

$\mathrm{LC}_{50}$ of $100-500 \mu \mathrm{g} / \mathrm{mL}$ are medium toxic; while extracts $\mathrm{LC}_{50}$ with $\mathrm{LC}_{50}$ of $0-100 \mu \mathrm{g} / \mathrm{mL}$ are highly toxic); NA = nonrated.

The processes of division and organogenesis are rapid in these periods of embryonic development, which allows us to consider the effects of mortality associated with the interaction between specific cellular mechanisms and the chemical compounds of the extracts analysed. The larvae in the Lythri herba aqueous extract, C1W, show no obvious cytological changes compared to the control group (Figure 3a). On the other hand, at $\mathrm{C} 2 \mathrm{~W}$ concentration, an increase of the cytoplasmic inclusions occurred (Figure 3b (1-detail), both at the level of the epidermal cells and in the digestive tract. The largest changes are noticed at $\mathrm{C} 3 \mathrm{~W}$, where mortality also occurred in the first 24 hours (Figure 3c).

In these, the cytoplasmic inclusions are numerous, but what differs is the manifestation of a phenomenon of inflatability of the terminal area, without changes to the digestive tract, which suggests the penetration and accumulation of the analysed extract through cell membranes, possibly in interstitial spaces (Figures 3c and $3 \mathrm{~d}$ ). Also, in $\mathrm{C} 3 \mathrm{Al}$, in the alcoholic extract, a detachment of the cells from the cuticle was noticed, which causes the entire cell mass to lose its adhesion. The consequences are obvious by the high mortality at $\mathrm{C} 3 \mathrm{Al}$, the explanation being related to the impossibility of the larva to hatch by losing the cellular support to the cuticle. In $\mathrm{C} 3 \mathrm{Al}$ in the alcoholic extract, the deformation of the entire digestive tract and, probably, structural ruptures are also evident, so that whole areas lose their normal structural appearance.

Studies on other types of test models have revealed similar phenomena, in the sense that Lythri herba extract causes the accumulation of cytoplasmic inclusions, increased the intercellular space and detachment of basement membrane cells [25].

In cells of the keratocyte type it is shown that the alcoholic extract of Lythri herba favours the synthesis of MMP1 (matrix metalloproteinase 1) and MMP3 (matrix metalloproteinase 3 ). Both are enzymes that participate in the remodelling of the extracellular matrix [18]. We consider this phenomenon similar to the biotester Artemia salina, causing the larvae to swell. 


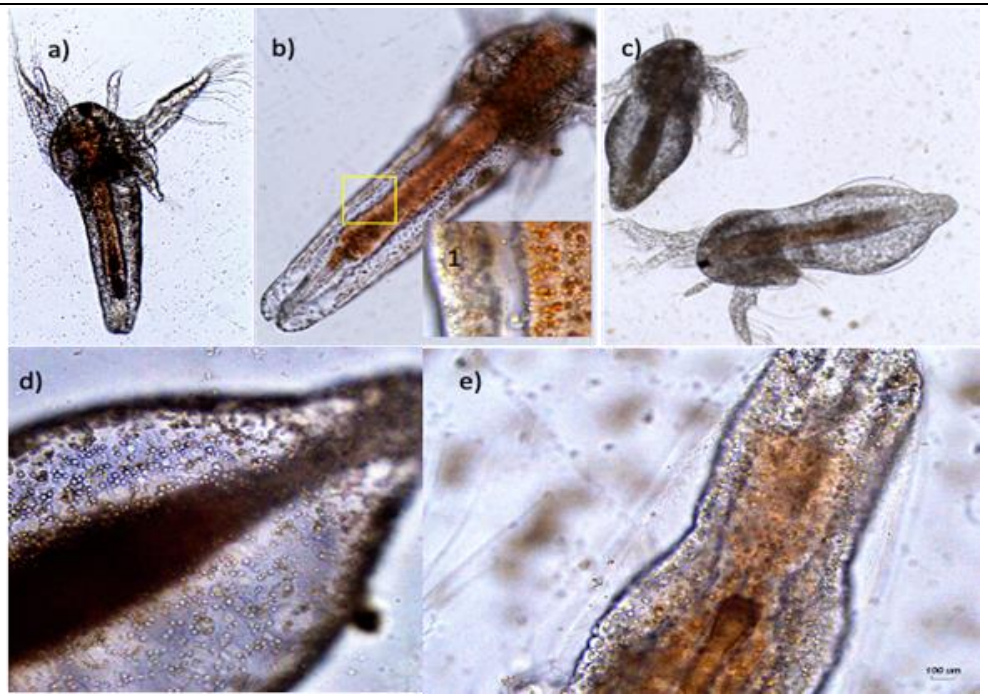

Figure 3.

Cellular changes induced by aqueous (W) and alcoholic (Al) extract of Lythri herba, under experimental conditions

a) control W, b) larvae exposed in aqueous extract, C2W, 1-detail, c) larvae exposed in aqueous extract, C3W, d) detail larvae exposed in aqueous extract, C3W, e) detail larvae exposed in alcoholic extract, C3Al. Unit measures $100 \mu \mathrm{m}$

The test model allows a rapid evaluation of the cytological effects induced by the chemical composition of the plant extract. The recording of mortality at extract concentrations higher than $1000 \mu \mathrm{g} / \mathrm{mL}$ suggests nontoxic activity which supports phytotherapy applications for the tested plant. Similar results on the low cytotoxicity of the Lythrum salicaria $\mathrm{L}$. analysed extract were also obtained on human cell cultures $[19,21]$.

\section{Conclusions}

Following the results obtained from the phytochemical investigation, we can say that, as an herbal medicinal product, Lythri herba has considerable amounts of total polyphenols and tannins, thus outlining the importance of the species in therapy.

The existence of polyphenols also justifies the antioxidant properties of the Lythri herba extract demonstrated in this study and the obtained results justify the orientation of research towards the determination of biological activities based on the reduction of the reactive oxygen species (ROS) levels.

Evaluating the biological activity of the Lythri herba extract by using BSLA led to determining the concentration of the extract with toxicological effects. The content in polyphenols and tannins, respectively, responsible for antioxidant activity of the extract and very low cytotoxicity are landmarks based on which the extract studied in phytotherapeutic applications can be estimated and recommended. This study contributes to the completion of phytochemical and cytotoxicological data to provide scientific support for traditional uses.

\section{Conflict of interest}

The authors declare no conflict of interest.

\section{References}

1. $* * *$ European Pharmacopoeia (EP), 10.0 edition, volume I, EDQM Council of Europe, Strassbourg, 2019; 1321, 1344, 1511.

2. $* * *$ Romanian Pharmacopoeia, $10^{\text {th }}$ Edition, Medical Publishing house, Bucharest, 2008; 1016, (available in Romanian).

3. Alihosseini F, Sun G, Functional Textiles for Improved Performance, Protection and Health. Woodhead Publishing, 2011; 17: 376-403.

4. Al-Snafi AE, Chemical Constituents and Pharmacological Effects of Lythrum salicaria - A review. J Pharmacy, 2019; 9(6): 51-59.

5. Apetroaei M, Paduretu C, Rau I, Schröder V, Newchitosan characterization and its bioassay in different salinity solutions using Artemia salina as bio tester. Chem Papers, 2018; 72(8): 1853-1860.

6. Bencsik T, Bartho L, Sandor V, Papp N, Benko R, Felinger A, Kilar F, Horvath G, Phytochemical evaluation of Lythrum salicaria extracts and their effects on guinea-pig ileum. Nat Prod Commun., 2013; 8(9): 1247-1250.

7. Bencsik T, Comparative Histological, Phytochemical, Microbiological and Pharmacological Characterization of Some Lythrum salicaria L. Populations, Ph.D. thesis, Hungary, 2014; 51-52.

8. Braguini WL, Alves BB, Pires NV, Toxicity assessment of Lavandula officinalis extracts in Brine Shrimp (Artemia salina). Toxicol Mech Meth., 2019; 29(6): 411-420.

9. Brglez Mojzer E, Knez Hrnčič M, Škerget M, Knez Ž, Bren U, Polyphenols: extraction methods, antioxidative action, bioavailability and anticarcinogenic effects. Molecules, 2016; 21(7): 901: 1-38.

10. Bucur L, Istudor V, Popescu A, Special pharmacognosy volume I - Oz, polyholosides, heterosides, lipids, Muntenia Publishing house, Constanța, 2004; 74-90, (available in Romanian). 
11. Bucur L, Ionus E, Moise G, Gîrd C, Schröder V, GC-MS analysis and bioactive properties of Zingiberis rhizoma essential oil. Farmacia, 2020; 68(2): 280-287.

12. Bușuricu F, Schröder V, Margaritti D, Nadolu D, Anghel AH, Preliminary study regarding sodium benzoate and other food dyes synergic action using BSLA cytotoxicity test. Scientific Papers. Series D. Animal Science, 2019; LXII(1): 410-415.

13. Clarkson C, Maharaj VJ, Crouch NR, Grace OM, Pillay P, Matsabisa MG, Bhagwandin N, Smith PJ, Folb PI, In vitro antiplasmodial activity of medicinal plants native to or naturalised in South Africa. $J$ Ethnopharmacol., 2004; 92(2-3): 177-191.

14. Coe FG, Parikh DM, Johnson CA, Anderson GJ, The good and the bad: alkaloid screening and brine shrimp bioassays of aqueous extracts of 31 medicinal plants of eastern Nicaragua. Pharm Biol., 2012; 50(3): 384-392.

15. Drăgănescu D, Lupuleasa D, Burcea-Dragomiroiu GTA, Roșca AC, Hîncu L, Cioaca D, 3D Printing Pharmaceutical formulation of drugs in personalized therapy. Farmacia, 2019; 67(1): 1-9.

16. Hong LS, Ibrahim D, Kassim J, Assessment of in vivo and in vitro cytotoxic activity of hydrolysable tannin extracted from Rhizophora apiculata barks. World J Microb Biotech., 2011; 27(11): 2737-2740.

17. Johari SA, Rasmussen K, Gulumian M, Ghazi-Khansari M, Tetarazako N, Kashiwada S, Asghari S, Park JW, Yu IJ, Introducing a new standardized nanomaterial environmental toxicity screening testing procedure, ISO/TS 20787: aquatic toxicity assessment of manufactured nanomaterials in saltwater Lakes using Artemia sp. nauplii. Toxicol Mech Meth., 2019; 29(2): 95-109.

18. Jouravel G, Guénin S, Bernard FX, Elfakir C, Bernard P, Himbert F, New biological activities of Lythrum salicaria L., Effects on keratinocytes, reconstructed epidermis and reconstructed skins, Applications in dermo-cosmetic sciences. Cosmetics, 2017; 4(4), 52: $1-16$.

19. Khanavi M, Moshteh M, Manayi A, Ardekani MRS, Vazirian M, Ajani Y, Ostad SN, Cytotoxic activity of Lythrum salicaria. Res J Biol Sci., 2011; 6, 55-57.

20. Khoo HE, Azlan A, Tang ST, Lim SM, Anthocyanidins and anthocyanins: colored pigments as food, pharmaceutical ingredients, and the potential health benefits. Food Nutr Res., 2017; 61(1): 1361779: 1-21.

21. Laitinen LA, Tammela PS, Galkin A, Vuorela HJ, Marvola ML, Vuorela PM, Effects of extracts of commonly consumed food supplements and food fractions on the permeability of drugs across Caco-2 cell monolayers. Pharm Res., 2004; 21(10): 1904-1916.

22. Manayi A, Khanavi M, Saiednia S, Azizi E, Vafi F, Malmir M, Siavashi F, Hadjiakhoondi A, Biological activity and microscopic characterization of Lythrum salicaria L. DARU J Pharmaceut Sci., 2013; 21(1): 61: 1-7.

23. Meyer BN Ferrigni NR, Putnam JE, Jacobsen LB, Nichols DE, Mclaughlin JL, Brine shrimp: a convenient general bioassay for active plant constituents. Planta Med., 1982; 45(5): 31-34.

24. Montanher ABP, Pizzolatti MG, Brighente IMC, An application of the brine shrimp bioassay for general screening of Brazilian medicinal plants. Acta Farm. Bonaerense, 2002; 21(3): 175-178.

25. Neto R, Gomes Junior PP, Silva MC, Lima CS, Yara R, Guimaraes EB, Vieira JR, Evaluation of embryotoxic and embryostatic effects of the aqueous extract of Rhizophora mangle and tannic acid on eggs and larvae of Aedes aegypti. An Acad Bras Ciênc., 2018; 90(2): 2141-2148.

26. Paris RR, Paris M, Sur les pigmentes anthocyaniques de la Salicaire (Lythrum salicaria L.). $C R L^{\prime}$ Acad Sci., 1964; 258: 361-364, (available in French).

27. Pârvu C, Plant encyclopaedia - plants from the flora of Romania, volume V, Tehnică Publishing house, Bucharest, 2005; 221-223.

28. Piwowarski JP, Granica S, Kiss AK, Lythrum salicaria L. - Underestimated medicinal plant from European traditional medicine, A review. J Ethnopharmacol., 2015; 170: 226-250.

29. Popovici V, Bucur LA, Schröder V, Gherghel D, Mihai CT, Caraiane A, Badea FC, Vochița G, Badea V, Evaluation of the Cytotoxic Activity of the Usnea barbata (L.) F. H. Wigg Dry Extract. Molecules, 2020; 25(8): 1865: 1-17.

30. Ricciotti E, Fitzgerald GA, Prostaglandins and inflammation. Arterioscler Thromb Vasc Biol., 2011; 31(5): 986-1000.

31. Schröder V, Arcuş M, Anghel AH, Bușuricu F, Lepădatu AC, Cell differention process of Artemia sp. larvae tools for natural products testing. Scientific Papers. Series D. Animal Sci., 2019; LXII(1): 149-153.

32. Tunalier Z, Koşar M, Küpeli E, Çaliș İ, Başer KHC, Antioxidant, anti-inflammatory, anti-nociceptive activities and composition of Lythrum salicaria L. extracts. $J$ Ethnopharmacol., 2007; 110(3): 539-547. 